\title{
Re-reading of the Farroupilha past at IHGB (1921-1935): Republican memory and intellectual legitimacies ${ }^{l}$
}

Mara Cristina de Matos Rodrigues[1]

\begin{abstract}
This paper addresses a re-reading of the Farroupilha War (1835-1845) at IHGB from the 1920's to the celebration of the conflict centenary in 1935, which ended up integrating it into the national historical memory. In this process, discursive and institutional strategies were triggered, regarding the political use of the past, the historiographical tradition of IHGB and the constructed intellectual legitimacies. Keywords: farroupilha memory; Brazilian historiography; IHGB.

A releitura do passado farroupilha no IHGB (1921-1935): memória republicana e legitimidades intelectuais
\end{abstract}

\section{Resumo}

O artigo trata da releitura da Guerra dos Farrapos (1835-1845) no IHGB, entre os anos 1920 e a comemoração do centenário do conflito, em 1935, que acabou por integrá-lo à memória histórica nacional. Neste processo, foram acionadas estratégias discursivas e institucionais, relacionadas ao uso político do passado, à tradição historiográfica do IHGB e às legitimidades intelectuais construídas.

Palavras-chave: memória farroupilha; historiografia brasileira; IHGB.

La relectura del pasado farroupilha en el IHGB (1921-1935): memoria republicana y legitimidades intelectuales

\section{Resumen}

El artículo trata de la relectura del passado farroupilha en el IHGB, entre los años 1920 y la conmemoración del centenario farroupilha, en 1935, que acabó por integrarlo a la memoria histórica nacional.En este proceso, fueron accionadas estrategias discursivas e institucionales, relacionadas al uso político del pasado, a la tradición historiográfica del IHGB y a las legitimidades intelectuales historicamente producidas. Palabras clave: memoria farroupilha; historiografía brasileña; IHGB.

\section{Relire du passé Farroupilha dans le IHGB (1921-1935): mémoire républicaine et légitimité intellectuelle}

\section{Résumé}

Cet article est une relire du passé Farroupilha dans le IHGB dans les années 1920 et la celebratión du centenaire de la revolutión Farroupilha dans 1935, qui a integré le evenement à la mémoire historique du pays. Dans ce processus, stratégies discursives et institutionnelles ont été chassés en ce qui concerne leur utilizatión dans la politique, la traditión historiographique du IHGB, et las légitimités intellectuelles produites historiquement.

Mots-clés: memoire farroupilha; historiographie brésilienne; IHGB.

Article received on January 10, 2013 and approved for publication on April 17, 2013.

[1] Department of History at Universidade Federal do Rio Grande do Sul (UFRGS) - Porto Alegre (RS) - Brazil. E-mail: mara.rodrigues@ufrgs.br

This paper was written as part of a junior post doctoral internship completed at the Graduate Program in History at Universidade Federal Fluminense in 2011. The research was funded by CNPq (National Council of Technological and Scientific Development) and supervised by Doctor Angela de Castro Gomes, whom I deeply thank for reading the first version of this text and for the fruitful exchanges during that period. I also would like to express my gratitude to the Scientific Initiation students under my supervision, Gabriela Correa da Silva and Marcelo Scarparo, and also to the Master's student Juliano Antoniolli, who contributed to this project. 
he year of 1935, which marks the end of the period addressed in this paper, already evidenced the result of the choices made in Rio Grande _ do Sul in regard to its inclusion in the scenario of Republican historical memory at IHGB (Instituto Histórico e Geográfico Brasileiro, Brazilian Historical and Geographic Institute): the Farroupilha Revolution, ${ }^{2}$ whose centenary was extensively celebrated in that year, has occupied, since then, a privileged space in the memory of this Southern State and in its articulation with national memory. In this paper, I consider the evident difficulties posed by the paradox of promoting an event that espoused a Republic separate from the Brazilian Empire as the best historical representative of Rio Grande's presence within the nation. In this sense, the main concern here is to comprehend how this process unfolded, and what were its main delineations in the sphere of the institutionalized historiographical production that was taking place at the national and the regional historical institutes in the early part of the $20^{\text {th }}$ century.

The corpus of the primary sources analyzed in this study is composed of session minutes and papers found in RIHGB (Revista do Instituto Histórico e Geográfico Brasileiro - Brazilian Historical and Geographic Institute Review) between the years of 1921 and 1935, along with minute sessions and papers found in RIHGRS (Revista do Instituto Histórico e Geográfico do Rio Grande do Sul - Rio Grande do Sul Historical and Geographic Institute Review). I also considered a few works produced outside of the institutionalized sphere of history, going back in time whenever necessary, to the extent that the length of this paper allows.

The criteria that defined the chronology of events adopted here are based on an important milestone in the institutionalization of history writing in Rio Grande do Sul, which occurred tardily in comparison to other States of the federation: the foundation of the IHGRS (Instituto Histórico e Geográfico do Rio Grande do Sul, Historical and Geographic Institute of Rio Grande do Sul) in 1920. In addition, the articulation between this time-frame and the delimitation of the primary sources aims at surpassing at least two tendencies that

\footnotetext{
${ }^{2}$ Farroupilha Revolution (1835-1845) was the name given to the civil war in which landlords and stockmen opposed the Imperial government and its representatives. The conflict took place in several parts of the province of Rio Grande de São Pedro, located in Brazil's southernmost region. The motivations behind it include economic matters, such as the breeders' and the jerky beef makers' demand that the imperial government protected the salty meat produced in the south in relation to the cheaper meat imported from Uruguay. Political motivations concerning the making of and the centralization of a Brazilian national State, ongoing since the country's independence in 1822, were added to economic problems. The rebels called themselves "farrapos", a term that denominated an extremist liberal movement that originated in the Court in 1831. The rebel movement was successful to a certain extent, given that, besides prolonging the conflict for almost 10 years, it attempted to establish a Republican government that proclaimed its autonomy from the Brazilian Empire. The conflict ended with a peace treaty that reintegrated the southern province to the Brazilian Empire, an advantageous solution for the farrapo leaders, but extremely detrimental to many slaves who had been freed during the war. See Cesar A. B. Guazzelli, "Fronteiras em conflito no espaço platino: da Guerra dos Farrapos à Guerra Grande", In: Luiz A. Grijó; Eduardo Santos Neumann (orgs.), O continente em armas: uma história da guerra no sul do Brasil, Rio de Janeiro, Apicuri, 2010, p. 97-122; Moacyr Flores, Modelo político dos farrapos, 4. ed., Porto Alegre, Mercado Aberto, 1996, p. 13-25.
} 
are verified in the studies on the historiography of Rio Grande do Sul, especially related to the IHGRS, since the 1980s. By focusing almost exclusively on the regional scenario, the first tendency ends up minimizing or even neglecting the articulation between the regional and the national spheres in regard to historiographical enterprises, and the making of a historical memory. ${ }^{3}$ I intended to show that at least a portion of the intellectuals, similar to what occurred with politicians, had their attention drawn towards the national context of power disputes and symbolic competition.

The other tendency limits the link between regional historiography especially that produced at the IHGRS - and national historiography almost exclusively to the legitimation of Getúlio Vargas' political ambitions as well as those of his supporters in the period studied. ${ }^{4}$ Even considering that the historical condition ${ }^{5}$ of historiography imposed certain social and political demands on its makers in a particularly constraining manner in this period, I sought to make this scenario more complex through the analysis of the problematic relations between the regional historical memory and the tradition of history writing at the IHGB. For this purpose, I focused on the discursive and institutional strategies of some of the IHGB's members that refer specifically to the study of Rio Grande do Sul's past.

From the point of view of the theoretical presuppositions that guide this work, I proceed to clarify some choices that have already been mentioned above, developing other reflections as the analysis of the primary sources unfolds. First of all, it is worth pointing out the placement of the present work within the approach that has been defined as history of historiography. I understand it as a historiographical operation in the terms proposed by Paul Ricoeur's appropriation of Michel de Certeau's concept. ${ }^{6}$ According to Ricoeur, there are inseparable relations between history writing and memory phenomenology that surpass their distinction within a simultaneously

\footnotetext{
${ }^{3}$ Among many works that can be cited as examples of this approach tendency at the IHGRS are: Marlene M. de Almeida, Introdução ao Estudo da Historiografia Sul-rio-grandense: inovações e recorrências do discurso oficial (1920-1935), Dissertação, Porto Alegre, IFCH-UFRGS, 1983; Sandra Pesavento, "Historiografia e ideologia". In: J. Dacanal; S. Gonzaga (orgs.), RS: Cultura e Ideologia, Porto Alegre, Mercado Aberto, 1996 [1980], p. 6088; and leda Gutfreind, A historiografia rio-grandense, 2. ed., Porto Alegre, UFRGS, 1998, although the latter offers quick references to the scenario of national historiography in that period. More recently, this tendency can be observed in the doctoral thesis written by the author of the present paper: Mara C. M. Rodrigues, Da crítica à história: Moysés Vellinho e a trama entre a província e a nação 1925 a 1964, Porto Alegre, PPGHUFRGS, 2006. Some works, generally produced outside Rio Grande do Sul, have distanced themselves from this perspective, such as Alexandre Lazzari's thesis Entre a grande e a pequena pátria: literatos, identidade gaúcha e nacionalidade (1860-1910), Campinas, IFCH-Unicamp, 2004, and Letícia B. Nedel's Um passado novo para uma história em crise: regionalistas e folcloristas no Rio Grande do Sul (1948-1965), Tese, PPGH/ ICH-UnB, 2005.

${ }^{4}$ Here I mention Gutfreind's dissertation again, leda Gutfreind, op cit. e Marlene M. de Almeida, op cit.

${ }^{5}$ The reflection about the historical condition of writing history, developed in the third part of Paul Ricoeur's work A memória, a história, o esquecimento, Campinas, Ed. Unicamp, 2007, was motivated by something that is also concerning to me in this paper: that which the author qualifies as "fair memory", i.e., a social practice that balances the excesses of memory and the excesses of forgetting.

\%/dem, Ibidem. Michel de Certeau, A escrita da história, Tradução de Maria de Lourdes Menezes, 2. ed., Rio de Janeiro, Forense Universitária, 2002.
} 
cognitive and pragmatic approach. ${ }^{7}$ Thus, this dual approach allows me to work with the articulation between these two types of representations of the past, which were characteristic of this period. ${ }^{8}$

In this paper, historiographical operations will be reflected upon particularly from the point of view of their inescapable relation with a determined time and place, keeping in mind the problematic relations between different regional memories in a context of renegotiation of national memory in favor of a historiographical representation that is more adequate to Brazil during the political-symbolical crisis that occurred between 1920 and 1930. I will develop my analysis based on the premise that if, on one hand, the horizon of expectations of national historiography - marked by the space of experience of the crisis faced by the 1920s political liberalism ${ }^{9}-$ did not authorize the abolition of all the past historiographical experiences, especially those that proposed re-reading Brazil's history through Republican lenses, ${ }^{10}$ on the other hand, its reinterpretation was required in order to meet the symbolic and material demands of the moment. Considering the modern concepts of temporal experience and history that are in force now, the most scathing transformations of the present time would open the doors to a new future and, therefore, require a new past.

\section{Breaking the silence: the disputes around the concept of Republic}

Among the most important materials on the history of the then-called 'Southern province' which appeared in the IHGB Review is "Guerra Civil do Rio Grande do Sul" ("The Civil War of Rio Grande do Sul"), a memoir written by Tristão de

\footnotetext{
"Paul Ricoeur, "L'écriture de l'histoire et la representation du passe", Annales HSS, jul-ago. 2000, n. 4, p. 731743. For the author, history shares with memory the same cognitive and pragmatic difficulties concerning the representation of the past: the aporia of the presence of something absent through an image, and the obstacles that interfere with the accuracy of memory or the truth of history: a halted, manipulated, and forced memory. According to Rüsen, historical culture has a triple dimension that is aesthetic, political, and cognitive. On the pages to follow, I was concerned, above all, with the political dimension of historiography, i.e., with the links between historians and the production of historical memory triggered with the purpose of constituting political legitimacy. Jörn Rüsen, Qué es la cultura histórica?: Reflexiones sobre una nueva manera de abordar la historia, Tradução de F. S. Costa e lb Schumacher, 1994. Available on: <http://www. culturahistorica.es/ruesen/cultura_historica.pdf>, access July 19, 2011.

${ }^{8}$ In order to complement this reflection, and to deal with the memorialist dimension of the historiographical operation of the beginning of the $2 \mathrm{O}^{\text {th }}$ century, we highlight the concept of historical memory, differentiating it from collective memory. This distinction fundamentally functions through the mark that the use prompted by political purposes confers to this practice of representation of the past, according to its appropriation by social groups, political parties, States or churches. Marie-Claire Lavabre, "De la notion de mémoire à la production des mémoires collectives”, In: Daniel C'efaï (dir.), Cultures politiques, Paris, PUF, 2001, p. 233-252. 9Reinhart Koselleck, "Espaço de experiência e horizonte de expectativa: duas categorias históricas", In: Futuro Passado, Tradução de Wilma Maas e Carlos Pereira, Rio de Janeiro, Contraponto, PUC-Rio, 2006, p. 305-328. ${ }^{10}$ This re-reading of national history had already been initiated in Republican propaganda starting in the last decades of the $19^{\text {th }}$ century, but it was particularly visible in the first decades of the Republican regime, when new events and heroes were elected as national symbols. On this topic, see, among others, Lúcia Lippi Oliveira, "As festas que a República manda guardar", Estudos Históricos, vol. 2, n. 4, Rio de Janeiro, 1989, p. 172189, José Murilo de Carvalho, "Tiradentes: um herói para a República", In: A formação das almas: o imaginário da República no Brasil, São Paulo, Cia das Letras, 1990, p. 55-73, Lúcia M. P. Guimarães, Da escola palatina ao silogeu: Instituto Histórico e Geográfico Brasileiro (1889-1938), Rio de Janeiro, Ed. Museu da República, 2006, and, more recently, Angela Gomes; Marta Abreu, A nova "Velha" República: um pouco de história e historiografia", Revista Tempo, vol. 13, n. 26, Niterói, 2009, p. 1-15.
} 
Alencar Araripe. ${ }^{11}$ Published in four parts, the first installment was released in $1880 .{ }^{12}$ After a long silence about such a controversial topic, the Review finally published a scientifically authorized version of the War of Farrapos. Until then, the Revolution of 1835 was not regarded as a historical object even among Rio Grande do Sul's inhabitants. Probably, the presence of ex-combatants of both sides or of their direct descendants in the political elite of Rio Grande do Sul, who were occupying positions of political and military power both in the local and in the national scenario, presented an obstacle for the elaboration of a well-accepted representation of that past conflict.

In Rio Grande do Sul, among the first attempts to write about this political and military event, are those undertaken by members of the Literary Parthenon, a cultural organization whose main purpose was to develop literary practices in the province, still incipient in the last and third part of the $19^{\text {th }}$ century. ${ }^{13}$ The IHGPSP (Instituto Histórico e Geográfico da Província de São Pedro, Historical and Geographic Institute of the Province of São Pedro), founded in 1860 but short-lived, did not approach the subject, although some of its members did so outside the institution, especially during political discussions. ${ }^{14}$

The fact is that Araripe's article - later turned into a book - caused a huge impact on the local political sphere, in the midst of Republican agitation, and propelled the writing of articles and other books that sought to portray the opposite of what was written by the ex-governor of the Southern province. One of the most well-known works about the Farroupilha Revolution appeared in the midst of this discussion: João Francisco de Assis Brasil's A república rio-grandense

\footnotetext{
"Counselor Tristão de Alencar Araripe was born in Ceará into a family of political tradition that acted in the revolutions of 1817 and 1824 . He was a magistrate and held several political positions in the Empire, among them that of governor of Rio Grande do Sul in 1876 and 1877, in the midst of the ascension of Republican propaganda in the State, as Afonso Celso, then IHGB's speaker, recalls in his obituary. He was a meritorious member of the IHGB, and his son, Araripe Júnior, was also a prominent politician, literary critic, and a member of the IHGB. RIHGB, t. 71, vol. 118, 1908, p. 607-608.

12"Guerra Civil do Rio Grande do Sul. Memória acompanhada de documentos, lida no Instituto Histórico e Geográfico do Brasil" was published in the following issues of the IHGB Review: RIHGB, t. 43, vol. 61, 1880; t. 45, vol. 65, 1882; t. 46, vol. 67, 1883; and t. 47, vol. 69, 1884. The last three parts simply presented the transcription of documents related to the conflict.

${ }^{13}$ There are at least two reports, released before 1868, provided by military men who participated in the conflict on the side of the Empire. Eduardo Scheidt, "O processo de construção da memória da Revolução Farroupilha", Revista de História, v. 147, São Paulo, 2002, p. 189-209. About the Literary Parthenon, see Alexandre Lazzari Entre a grande e a pequena pátria: literatos, identidade gaúcha e nacionalidade (1860-1910), Tese, Campinas, IFCHUnicamp, 2004: Cássia D. M. da Silveira, Dois pra lá, dois pra cá: o Parthenon Literário e as trocas entre a literatura e política na Porto Alegre do século XIX, Dissertação, Porto Alegre, PPGH-UFRGS, 2008, and Luciana F. Boeira, Entre a história e a literatura: a formação do panteão rio-grandense e os primórdios da escrita da história do Rio Grande do Sul no século XIX, Dissertação, Porto Alegre, PPGH - UFRGS, 2009.

${ }^{14}$ Alexandre Lazzari, op cit. p. 207. The desire to break the silence about the Civil War comes to fruition in literature. According to Boeira, although the Historical and Geographic Institute of the Province of São Pedro Review, published between 1860 and 1863, did not register stories or memories about the event, it displayed some documents produced by the rebels. Luciana Fernandes Boeira, Como salvar do esquecimento os atos bravos do passado rio-grandense: a Província de São Pedro como um problema político-historiográfico no Brasil Imperial. Qualif. Dout. Porto Alegre, PPGH, UFRGS, 2011 (mimeo). On Farroupilha memory focused on literature in the $19^{\text {th }}$ century, see also Sandra Pesavento, "Uma certa Revolução Farroupilha". In: Keila Grinberg; Ricardo Salles (orgs.), O Brasil Imperial. Vol II - 1831-1870, Rio de Janeiro, Civilização Brasileira, 2009, p. 233-267.
} 
(The Republic of Rio Grande do Sul), ${ }^{15}$ which opposed Araripe's "legalist" version. ${ }^{16}$ This work was widely circulated, including outside of Rio Grande do Sul, and it decisively marked what was thought and written about the Farroupilha Revolution in the subsequent decades. ${ }^{17}$

The understanding of this first controversy about the Farroupilha Revolution is important in advancing into further analysis about the way the re-reading and rehabilitation of the past functioned in the beginning of the $20^{\text {th }}$ century. However, before proceeding to the exposition of the theses defended by the authors in question, it is important to highlight the fact that, right at the start of the making of the farroupilha historical memory, the people from Rio Grande do Sul involved in this process of memory-framing paid special attention to what was thought and said outside of Rio Grande do Sul, in terms of political models and national memory. ${ }^{18}$ For instance, Assis Brasil did not refer exclusively to local political disputes, although evidently, they had an important role for the men devoted to the reiterated search for the State's administrative autonomy. Nevertheless, even though the struggle around federalism was significant in the final years of the Empire, and although this was the model selected for the distribution of national political power in the period that followed the proclamation of the Republic, the vindications for autonomy were made with an eye on local interests and another on the most pressing national matters. It would not be different with the writing of history.

Right from the title, Araripe's text names the armed struggle between farroupilha and the imperial forces a "civil war", and not a "revolution". However, this is not a complete rejection of the meaning of the word 'revolution' when designating the conflict, given that this word is used in the body of the text: "the revolution began under the guise of sedition, vacillated about its procedure, until it took on the character of a rebellion in 1836 and proclaimed the Republic". ${ }^{19}$ Besides the preference given to the concept of "civil war" instead of "revolution", the author affirmed that the civil war was captained, on the rebels' side, by caudilhos ${ }^{20}$ who chiefly placed their own private interests over those of the nation. In this way, Araripe targeted one of the main arguments espoused by the Republican propaganda, especially by the group of students

\footnotetext{
15João Francisco de Assis Brasil integrated the Republican generation of people from Rio Grande do Sul who studied at Faculdade de Direito de São Paulo (Law School of São Paulo). About the other members of the group of "federalist positivist gaucho people" and the ideas they defended in the 1870s, see Ângela Alonso, Ideias em movimento: a geração 1870 na crise do Brasil-Império, São Paulo, Paz e Terra, 2002, p. 155-159. ${ }^{16}$ Joaquim Francisco de Assis Brasil, História da República Rio-Grandense. Porto Alegre, Cia União de Seguros Gerais, 1982 [1881], ERUS (Estante Rio-Grandense União de Seguros).

${ }^{17}$ On the circulation of Assis Brasil's work, see Alexandre Lazzari, thesis Entre a grande e a pequena pátria: literatos, identidade gaúcha e nacionalidade (1860-1910), Campinas, IFCH-Unicamp, 2004, p. 222 et seq. A República federal (The Federal Republic), written by the same author before the work in question, was even more circulated. Maria Tereza C. de Mello, "A modernidade republicana", Revista Tempo, n. 26, Niterói, UFF, 2009, p. 15-31. See p. 16.

${ }^{18}$ The concept of "memory framing" presupposes that memory is not formed arbitrarily; instead, it feeds on productions inherited from history. Michael Pollak, "Memória, esquecimento, silêncio", Estudos Históricos, vol. 2, n. 3, Rio de Janeiro, 1989, p. 3-15.

${ }^{19}$ RIHGB, t. 43, vol. 61, 1880, p.155-116.

${ }^{20}$ In Portuguese, the word caudilho has the same meaning than the Spanish term caudillo, which designates military chiefs peculiar to South America during the $19^{\text {th }}$ century who competed against politically centralized powers.
} 
of the Law School of São Paulo who integrated the Clube Vinte de Setembro (September Twentieth Club). A former member of the IHGB, the ex-governor of the province posed a huge obstacle to those who intended to legitimate the struggles of the present with the pretensions and achievements of past heroes.

Araripe's affiliation with a former leader of the Confederation of Ecuador seemed to be an important support that authorized him to deny the Republican character of the Farrapos movement and to weaken its revolutionary dimension, attributes recognized by the author in the Confederation attempted in Pernambuco and Ceará. According to the author, the inhabitants of these States were the true Republicans because they prioritized the cause of democracy, while the farrapos used this ideal to better defend their private goals within a regime he called "military despotism".21 From this perspective, the struggle for Republican ideals, when identified with democracy, were legitimate but the latter did not apply to the case of the rebellion shown by leaders from Rio Grande do Sul, who acted in detriment of collective interests. For the author, the conflict between Farroupilha people and the Empire represented the opposite of a model of Republican movement. However, if the ideological (Republican) struggle could not be called upon as a favorable argument to the leaders of the

\section{The struggle for Republican ideals, when identified with democracy, were legitimate but the latter did not apply to the case of the rebellion shown by leaders from Rio Grande do Sul}

farrapos in Araripe's perspective, the author did not go to the extent of accusing them of separatism, and highlighted that, if such was their intention, they would have promptly sought an approximation with neighboring republics after the proclamation of the Piratini Republic, which did not occur. ${ }^{22}$

Assis Brasil wrote his version of the Farroupilha Revolution immediately after the publication of Araripe's book because of a request made by the September Twentieth Club of the Law School of São Paulo. The very name of the club where the Republican students gathered evidences that, despite the historiographical silence, the use of the Farroupilha past constituted an ideological weapon on the political plane. ${ }^{23}$ The author initiated his book by

\footnotetext{
${ }^{21}$ RIHGB, t. 43, vol. 61, 1880, p. 118

22/dem, Ibidem, p. 121.

${ }^{23}$ For Koselleck, one of the characteristics associated with the emergence of modern political and social concepts is that of ideologization and its use as a political weapon and a way of producing behaviors. From this perspective, it is not the concept of revolution per se that undergoes a process of modernization, but that of Republic, whose meanings are disputed by the two historiographical versions of the Farroupilha Revolution. Koselleck, "Espaço de experiência e horizonte de expectativa: duas categorias históricas", In: ___., Futuro Passado, Tradução de Wilma Maas e Carlos Pereira, Rio de Janeiro, Contraponto, PUC-Rio, 2006, p. 102.
} 
referring to this incumbency and to the little time he had to address it. He revealed a deep admiration for Araripe's book, and confessed that he owed the inspiration behind his work to it, even though he manifested "fundamental disagreement" with his ideas and even with some facts that were narrated by Araripe. ${ }^{24}$

One of the fundamental differences between the theses of these two authors is found in the causes presented for the "revolution". For Araripe, as we have seen, what ignited the conflict was chiefly the private interests of Rio Grande do Sul's caudilhos. For Assis Brasil, on the other hand, the revolution was a natural consequence of the contradiction that existed between the centralized institutions of the Imperial government and the nature and character of the province's people. A country as extensive as Brazil could not be governed by the same institutions and rules from north to south. However, Assis Brasil did not fail to point out the similarities between the upset feelings that reigned in Rio Grande and those that were also verified in other Brazilian provinces in regard to the uniformity forced by Imperial politics in the 1830s. ${ }^{25}$ Although he emphasized, in another book, the differences that justified the autonomy of the provinces, vindicated by defenders of federalism, Assis Brasil had already reflected upon the limits of distinguishing the people of Rio Grande do Sul from the rest of Brazil, which did not necessarily isolated them as platinos. ${ }^{26}$

In regard to the presence of Republican ideas, the author affirmed that, before Tito Lívio Zambeccari, one of the Italians who fought alongside the farrapos, no one else advocated in favor of the Republic. For Assis Brasil, Zambeccari was the revolution's "mastermind", which meant that the origins of the Farroupilha Republicanism were placed upon Europe and not upon the republics along the Plate River. At the same time, the idea of a revolution already existed outside of Rio Grande, as Bento Gonçalves had adopted it in Rio de Janeiro alongside men such as Evaristo da Veiga. ${ }^{27}$

Thus, in this brief analysis of the texts written by Araripe and Assis Brasil, the strict association between the concepts of revolution and Republic looms in

\footnotetext{
${ }^{24}$ Assis Brasil, História da República Rio-Grandense. Porto Alegre, Cia União de Seguros Gerais, 1982 [1881], ERUS (Estante Rio-Grandense União de Seguros), p. IX. According to Lazzari, the September Twentieth Club, integrated by Julio de Castilhos, Joaquim Francisco de Assis Brasil, and Homero Baptista (future member of the IHGB), among others, sent letters to several intellectuals, ex-combatants, and others who potentially had valuable information, documents, and testimonials that could be used to "correct the distortions" made by Araripe. Alexandre Lazzari, Entre a grande e a pequena pátria: literatos, identidade gaúcha e nacionalidade (1860-1910), Tese, Campinas, IFCH-Unicamp, 2004, p. 216-217.

${ }^{25}$ Assis Brasil, op cit. p. 52-53.

${ }^{26}$ According to Lazzari in reference to Assis Brasil, A República Federal. Alexandre Lazzari, op cit. p. 222-223. The word "platino", written identically in Portuguese and Spanish, designates people from regions around the Plate River, that is, Argentines and Uruguayans. I used it here with the purpose of affirming the pertinence of Rio Grande do Sul's people to Brazil, despite their cultural similarities with neighboring countries.

${ }^{27}$ Assis Brasil, op cit. p. 56-58.
} 
both texts as almost interchangeable terms ${ }^{28}$ However, if both authors agreed on this proximity, on the other hand, Republic and revolution explained the Farroupilha conflict with inverted signs: negatively for Araripe, and positively for Assis Brasil. The fact is that these texts were regarded as the main references about the Farroupilha Revolution for decades. At the IHGB, Araripe's authority on the subject seemed to go beyond his death in 1908, given that there was no other article or speech that clearly contested his version until 1921, even in the midst of the emergence of a new Brazilian memory after the proclamation of the Republic. This period of silence would be broken in the beginning of the 1920s, when the revolution became the object of celebrations and debates until the 1930s.

\section{From caudilhos to heroes: first rehabilitation at the IHGB, and the meaning of patriotism}

Although other texts of a caliber equivalent to Araripe's were not published in the IHGB Review about the Farroupilha Revolution, at least not until its centenary in 1935, this gap in the historiographical field does not apply to the construction of the historical memory particular to Rio Grande do Sul, especially the Farroupilha memory. ${ }^{29}$ If the War of Farrapos was not present in the most erudite and scientifically legitimated textual elaborations in the Review, it was in the scope of celebrations and speeches published in the IHGB's minutes that it emerged as an important topic of national memory. After Rio Grande do Sul's political elite class trimmed its edges and "put the house in order", the State projected itself nationally as a political and symbolic force. ${ }^{30}$

\footnotetext{
${ }^{28^{\prime \prime}}$ In the final decades of the Empire, the word Republic expanded its semantic field, incorporating the ideas of freedom, progress, science, and democracy, terms that pointed, all of them, towards a desired future". Mello, "A modernidade republicana", Revista Tempo, n. 26, Niterói, UFF, 2009, p. 16.

${ }^{29}$ In the $19^{\text {th }}$ century, Rio Grande do Sul was the second Brazilian province most cited in the papers published in the IHGB Review. Luciana Boeira, Como salvar do esquecimento os atos bravos do passado rio-grandense: a Província de São Pedro como um problema político-historiográfico no Brasil Imperial. Tese de Doutorado, Universidade Federal do Rio Grande do Sul, Porto Alegre, 2013. Thus, in comparison to the preceding century, the presence of this State as a historiographical problem was discreet in the period that I cover here. Rio Grande do Sul's past was the object of three articles between 1914 and 1921: two about the Jesuits' Missions, and one about the campaign for the War of Paraguay in Rio Grande do Sul. RIHGB, t. 77 , v. 130, 1914, p. 51-66 and p. 181-190, and /dem, t. 85, v. 139, 1919, p. 107-278.

${ }^{30}$ In 1921, representatives of the two most prominent political parties combined their efforts at the recently founded IHGRS for the cause of keeping the State's glorious past safe from oblivion. In 1923, the last big dispute occurred between partisans and adversaries of the long-standing governor Borges de Medeiros in Rio Grande do Sul. With the unfolding of the 1923 Revolution, a space was opened in 1928 for an alliance between Rio Grande's Republican Party (PRR), the governing party in Republican times, and the oppositional Liberal Party (PL) that espoused Getúlio Vargas. On this topic, among many other titles, see Joseph Love's O regionalismo gaúcho e as origens da Revolução de 1930, São Paulo, Perspectiva, 1975 and "A república brasileira: federalismo e regionalismo (1889-1937)", In: Carlos Guilherme Mota (org.), Viagem incompleta: a experiência brasileira (1500-2000). A grande transação. 2. ed. São Paulo, Editora SENAC SP, 2000, p. 121-160; Luiz A. Grijó, "Entre a barbárie e a civilização: os conflitos armados no período republicano", In: Eduardo Santos Neumann; Luiz Alberto Grijó (orgs.), O continente em armas: uma história da guerra no sul do Brasil. Rio de Janeiro, Apicuri, 2010, p. 159-184.
} 
With this approach, I do not intend to presuppose an amalgamation or a radical opposition between the enterprises of history and of national historical memory at that moment. At first, as a hypothetical study, I seek to preserve the distinction between history, understood as an operation of more critical purport in reconstructing the past, and a historical memory marked by the political use of the past, as I have previously mentioned. From this perspective, both operations can find space in the same institution at different moments. Historical memory, venerated more ostensibly in the sphere of celebratory events, conferences, and civic actions, construed with the participation of national and regional historical institutes, had the possibility of being criticized on the basis of the normative criteria of such institutions as a factor that counterbalanced its emotional and political appeal.

From a perspective that seeks to include strategies of the social place of history production, reflected upon here both in its institutional configuration and its sociopolitical inclusion as an inseparable part of historiographical operations within a certain time and space, I proceed to reflect about the recruitment of "historians" from Rio Grande by the IHGB. ${ }^{31}$ Before 1920, the presence of only six individuals from Rio Grande do Sul was registered among

If the Farrapos leaders had truly been neither
Republicans nor separatists, what led General Netto
to proclaim the Republic of Piratini?

163 members of the IHGB. ${ }^{32}$ In the following year, 1921, three members of the recently created regional institute (IHGRS) joined the national institution as correspondent members. Two of them were Jesuit priests - one had already contributed for the IHGB Review - and the other was Colonel-Lieutenant

\footnotetext{
${ }^{31}$ As we will see further ahead, some nominations for members were more politically marked than others, although attention was always paid to the statutory formality that prescribed the analysis of a candidate's work by one of the specialized committees (of history, archeology and ethnography, or geography, for instance), and another one by the committee of admission and members. About the profile of the IHGB's historians, Angela Gomes considers its condition imprecise and still an object of debate in the specific context where the intersection of the intellectual and political spheres was verified in Brazil at the end of the $19^{\text {th }}$ century and beginning of the $20^{\text {th }}$ century. Angela de Castro Gomes, A República, a História e o IHGB, Belo Horizonte, Argumentum, 2009, p. 26.

32They are Homero Baptista, Arthur da Rocha Pinto, Rivadávia Corrêa, Almirante Arthur Índio do Brasil, and Ramiz Galvão, all living in Rio de Janeiro. In addition to these was Marshal Hermes, also the honorary president because he had been the Republic's president. Among the 64 correspondent members, a category that expresses more effectively the type of historian who lives in his State and deals with matters that concern his region, there was no one living in Rio Grande do Sul. See the 1920 list of members in RIHGB, t. 84, v. 138, 1918, p. 703-711. Rivadávia Corrêa, who still appeared on the 1919 list, does not have his name on the one composed in 1920 because he died in the meantime. RIHGB, 1918, t. 83, v. 137, p. 598. As we will see further ahead, the fact that these individuals were born in Rio Grande do Sul did not necessarily make them "regional historians".
} 
Emílio Fernandes de Souza Docca, the new regional institution's speaker. ${ }^{33}$ If the candidacy of the Jesuit priests seem to have been based more on their scientific qualities and merits, Souza Docca's seems to have followed mixed criteria, given that he was regionally known more for his patriotic tone than for his erudite endowments. ${ }^{34}$ Although the presence of members was numerically discreet at the new IHGB institute, since only Souza Docca took his position in the group, a convergence between the two institutions is evident from the foundation of the IHGRS, and it can be observed from the emergence of discussions related to Rio Grande do Sul on the national institutional agenda.

By briefly following the trajectory of the members from Rio Grande do Sul at the IHGB before 1921, we can affirm that some nominations did not prioritize intellectual merit. The reports written by the history committee and the nominated members' committee leave no doubt, for instance, about the predominantly political character of Rivadávia Correa's and Homero Baptista's nominations when they were active in Marshal Hermes da Fonseca's government. ${ }^{35}$ Only Arthur da Rocha Pinto and Ramiz Galvão had their candidacies justified, above all, by their intellectual production. ${ }^{36}$ Among these members, none of them identified with the writing of a history that was chiefly connected to the regional past. However, Homero Baptista delivered a speech related, albeit indirectly, to the topic of the Farroupilha Revolution, published in 1918 and titled "Revoluções Brasileiras de 1817 a 1835" ("Brazilian Revolutions from 1817 to

\footnotetext{
${ }^{33}$ Besides the Colonel-Lieutenant, the other two members were the Jesuit priests Carlos Teschauer and João Batista Hafkemeyer. Out of the three members that entered the institution in 1921, only Souza Docca took his position in the same year, subsequently reaching the status of full member of the institution. RIHGB, t. 87, vol. 141, 1920, p. 537 et seq.

${ }^{34} \mathrm{His}$ position as IHGRS' speaker also seems to have obeyed criteria that were more political than academic. The Jesuit priests, the novel writer Alcides Maya and his future contender, Alfredo Varella, for instance, had an intellectual capital more consolidated than Souza Docca's. However, it is difficult to categorize him as a historian politician, since, although he is mentioned in historiographical versions that tend to be used officially by the government of Rio Grande do Sul and Brazil, he never occupied prominent political positions. Moreover, he used to identify himself first as a soldier and then as a historian, which is verified in two of the first speeches he delivered at the regional and national institutes. RIHGRS, 30 trim., 1921, p. 57-67; RIHGB, t. 90, vol. 144, 1921, p. 825-836.

${ }^{35}$ Rivadávia Corrêa was nominated to be considered, along with another State minister, as an honorary member of the institution with an explicitly political intention. In his nomination, references were made to his position as a Minister of Justice and Home Affairs. Historical works authored by him were not appointed as merits in favor of his entry into the institution; instead, mention was made to his active role in the recent Education Reform and the "notable services" he performed for the Institute, which commended him to the gratitude of its members. Homero Batista joined the IHGB as a correspondent member in 1911, but it was his nomination to become an honorary member in 1914 that was markedly political. At this time, Baptista was already a full member, since he lived in the federal capital, because of his activities in Marshal Hermes' government. The double justification presented during his nomination as an honorary member refers to the "outstanding services" provided by him to the Institute, both in his performance of social assignments and as a representative of the nation. These services could range from obtaining governmental grants for study trips to assistance for the institution's publications. RIHGB, t. 75, vol. 126, 1912, p. 240; Idem, t. 74, vol. 124, 1911, p. 519 and 545-46; Idem, t. 77, vol. 130, p. 511.

${ }^{36}$ Arthur da Rocha Pinto was a magistrate and university professor in Rio de Janeiro. He had collaborated with the IHGB as a guest in a course promoted in 1915. Although Ramiz Galvão was from Rio Grande do Sul and invoked this origin in his speeches, he had already been completely integrated into the political and professional social circles of the federal capital since the time of the Imperial Court. His last position in the Empire was as a tutor of Princess Isabel's children. Before that, he had already joined the Institute as a full member. His position at the IHGB, therefore, owes nothing to his political or symbolic relations with Rio Grande do Sul. RIHGB, t. 78, vol. 132, 1915, p. 639, 671-2. Along with Max Fleuiss and Count de Afonso Celso, Rocha Pinto was part of the so called "Silogeu's trinity", responsible for uplifting the IHGB after Baron de Rio Branco's death in 1912. Lúcia M. P. Guimarães, Da escola palatina ao silogeu: Instituto Histórico e Geográfico Brasileiro (1889-1938), Rio de Janeiro, Ed. Museu da República, 2006.
} 
1835"). ${ }^{37}$ Baptista had also been a member of the September Twentieth Club, which had commissioned the book about the Farroupilha Revolution written by Assis Brasil. However, despite this proximity between the two, the book República Rio-grandense (Republic of Rio Grande) was not a privileged source for Baptista and it was not even cited by him. The work mentioned during the conference was significantly less known inside and outside the Southern State, written by Alfredo Ferreira Rodrigues and titled A pacificação do Rio Grande do Sul (The pacification of Rio Grande do Sul). ${ }^{38}$ For Baptista, the Farroupilha Revolution was a legitimate movement of reaction to governmental policies, similar to others that had occurred during the Imperial period. For this reason, he included it in the series of Brazilian revolutions that happened between 1817 and 1838. He did not, however, invest it with a privileged or highlighted character in comparison to the other movements. In this case, the concept of revolution relates primarily to a struggle against the Monarchy, and it recaptures an interchangeable meaning with the concept of Republic.

It was Souza Docca who initiated, more explicitly, the process of rehabilitating the Farroupilha leaders in national historical memory. ${ }^{39}$ Although he was not the first person from Rio Grande do Sul to be remembered as a potential member of the IHGB in 1921, he was the most active of the three who joined in that year, reaching the status of full member a few years later. His candidacy was supported by Max Fleiuss, who explicitly referred to the Colonel-Lieutenant's book about the War of Paraguay on one of his annual reports. Although the Jesuit priests who were nominated as correspondents with Souza Docca in 1921 were apparently highly estimated because of their historiographical work, they never took the position. Perhaps due to a wider mobility because of his military assignments, the ColonelLieutenant was in Rio de Janeiro on September 19, 1921, when he accepted the position offered and delivered the usual speech. Although his nomination was based on his work about the War of Paraguay, his address dealt with the Farroupilha Revolution, which would complete its $86^{\text {th }}$ anniversary on the following day. ${ }^{40}$

This time, indeed, a clear differentiation can be perceived between the version proposed by Araripe in the 1880s and the one created by Docca well into the second

\footnotetext{
${ }^{37} R / H G B$, t. 83, vol. 137, 1918, p. 340-349.

${ }^{38}$ Ferreira had also been a correspondent member of the IHGB. He joined the institute in the beginning of the Republican period. Among his works evaluated by the committee of history were some biographical drafts of the lives of Farrapos leaders, such as Davi Canabarro. Idem, t. 59, vol. 94, 1896, p. 243, 274.

39| intentionally appropriate the term "rehabilitation", used by Aurelio Porto, a historian contemporary to Souza Docca and also a member of the IHGRS, in a text published in RIHGRS, 20 trim., 1934, p. 309320: "Processos dos Farrapos: Reabilitação de Bento Gonçalves". The text deals with the publication of documents from the $19^{\text {th }}$ century that supposedly proved Bento Gonçalves' loyalty to the Brazilian Empire when the Cisplatine War was about to erupt.

${ }^{40}$ According to a preliminary data collection, this seems to be the first "celebration" of the Farroupilha Revolution's anniversary at the IHGB. I did not detect any celebratory session in the years in which the anniversary was marked by a "round number", such as in 1905 and 1915, for instance, when the conflict completed 70 and 80 years respectively. In the celebratory writings of Baron de Rio Branco, published in 1917, he makes references to September $20^{\text {th }}$, as it was expected, coming across as discreetly in favor of the Empire, but without showing disapproval for the insurgents. RIHGB, t. 82, vol. 136, 1917, p 452-453. It is important to mention that Afonso Celso's tone, preceded by S. Docca's speech, also remarked that the episode should serve as a lesson, but in the sense of what should be done in order to avoid new separatist enterprises. Idem, t. 90, vol. 144, p. 837.
} 
decade of the $20^{\text {th }}$ century. Firstly, it is necessary to mention that, in many aspects, the 1921 text is not completely different from Araripe's in regard to the sequence of the facts and the non Republican character of the movement. For Docca, as well as for Araripe, the Farrapos leaders were neither separatists nor Republicans by principle. For the former, the circumstances of the conflict led them towards the proclamation of the Republic and to a separation from the Empire; for the latter, the reasons behind the proclamation and this separation were due to caudilhos' private interests. Thus, the main difference between the author from Rio Grande do Sul and the one from Ceará concerns the moral character and the patriotism of the Farroupilha leaders. For Souza Docca, it was less important, at that moment, to accentuate the Republican character of the movement than to clean the image of the Southern revolutionaries by removing the aura of caudilhismo attached to them.

The first words of Souza Docca's speech denounce a certain care, probably explained by the presence at the IHGB of many members who had been close to and even participated in the Monarchic government in the past years. The historian debuting at the national institute was supposed to address an audience of former Monarchists, but also of active figures of the Republican regime, among them Homero Baptista, whose origins were the same as his. ${ }^{41}$ Although the process of readjusting the IHGB's practice and discourse to the new regime was already advanced, ${ }^{42}$ Docca still seemed uncomfortable with this contradictory coexistence. Thus, he opted for accentuating the patriotism and the praiseworthy intentions of the Farroupilha leaders:

I feel happy for being able to begin by affirming that Bento Gonçalves, Bento Manuel, Canabarro, and Netto were never separatists in their hearts. Neither did they have ingrained Republican ideas. This does not diminish them in any way, because our greatest men must not be venerated by the simple fact that they were Republicans or monarchists, but because they knew how to be one or the other while being, always and above all, Brazilians. ${ }^{43}$

Either because of the fear of offending his audience or due to the precarious state of historical research conducted on the subject at that moment, Docca also sought to justify the most important Farroupilha men by equating them to other renowned names of national history, especially those who were dear to the IHGB, such as Baron de Rio Branco and Joaquim Nabuco, both Monarchists who held important positions in Republican diplomacy. ${ }^{44}$

\footnotetext{
${ }^{41}$ According to Lúcia Paschoal Guimarães, Da escola palatina ao silogeu: Instituto Histórico e Geográfico Brasileiro (1889-1938), Rio de Janeiro, Ed. Museu da República, 2006, one of the most successful strategies to preserve the Institute's financial integrity and cultural importance after the proclamation of the Republic was adopted by the board of directors headed by Afonso Celso, Max Fleiuss and Ramiz Galvão: from 1912 onwards, they started admitting prominent figures of the Republican governments into the IHGB as members. Furthermore, the discourse and the national memory propagated at the institution were transformed to adequate themselves to the demands of the new regime, but care was taken, all the while, to avoid tainting the memory of Emperor Pedro II, the institution's main benefactor.

${ }^{42}$ This is what Angela Gomes affirms about the IHGB during the period in question. Gomes, A República, a História e o IHGB, Belo Horizonte, Argumentum, 2009, p. 30.

${ }^{43}$ RIHGB, t. 90, vol. 144, 1921, p. 825.

44/dem, Ibidem, p. 827.
} 
The question arises: if the Farrapos leaders had truly been neither Republicans nor separatists, what led General Netto to proclaim the Republic of Piratini? How was one to explain the significantly close relations between the Farroupilha men and important caudilhos of the Prata region, such as Lavalleja and Fructuoso Rivera? In spite of the volubility attributed to Bento Gonçalves, the greatest responsibility for the movement's contradictions fell on Republican agitators, and, secondly, on the people. For Docca, the first had carried the situation over to the side that was in favor of a Republic and of separation, given that their action "deeply silenced the people's spirits, always predisposed to rebellions and riots. Consequently, one can say that almost the entire Rio Grande do Sul stood up for the revolution on September twentieth as one single man". ${ }^{45}$ These agitators came mainly from other Brazilian provinces and from abroad. They were Italian carbonari, such as Tito Lívio Zambeccari and Giuseppe Garibaldi and other inciters from other countries who lived along the Prata River. Thus, the Republic was not the result of a natural and irresistible force, as Assis Brasil affirmed, but of oftentimes malicious exterior forces.

This interpretation of the facts would be revised by Souza Docca in later years, either because he was more adapted and less apprehensive in the imposing dwelling of national history, because he had furthered his knowledge about the Farrapos' process or because he noticed a necessity of including Rio Grande do Sul in the national Republican memory. However, what was seen in 1921 was a man from Rio Grande do Sul, proclaiming during a conference at the IHGB, that Bento Gonçalves was a well-intentioned leader, but also volatile and easily influenced; ${ }^{46}$ that the Republic was not an atavistic force in Rio Grande, given that it was successful because of the work of Republicans from other Brazilian provinces and from abroad who had brought their bad influence to the farrapos; and finally, that the gaucho people were accustomed to violence and disorder. Perhaps Araripe's version was overall less derogatory to the people from Rio Grande do Sul than this one delivered by Docca. However, the four main Farroupilha leaders - among them both Bentos, Canabarro and Netto - were saved from the bad image of caudilhos and separatists. Instead, the epithet of "centaurs" was attributed to them, used in local literature since the $19^{\text {th }}$ century to generically

\footnotetext{
${ }^{45}$ R/HGB, t. 90, vol. 144, 1921, p. 831.

${ }^{46}$ It is important to highlight that the ambiguous role attributed to Bento Gonçalves da Silva at that moment, when his memory did not yet enjoy the immense prestige it would reach at the Farroupilha centenary and in the subsequent years up to this day in Rio Grande do Sul. In this sense, the discussions registered in the IHGB's internal session minutes at the time of the centenary demonstrate the consolidation of his figure as the greatest hero among the Farrapos. The session that occurred on April 11, 1933 especially marks the hierarchization of the symbolic values at stake. On this occasion, the effigies that would appear on celebratory coins and their respective values were chosen. The coin with Bento Gonçalves's effigy was the highest in value, followed by the one that showed Duke de Caxias. The same did not occur with stamps, given that the highest in value was the one that displayed Duke de Caxias, while Bento Gonçalves was assigned the $10^{\text {th }}$ position among 16 remarkable heroes and events of the revolution. Nevertheless, it is valid to ask if Bento's stamp was among those that would circulate the most because of its accessible price. RIHGRS, 40 trim., 1933, p. 295-297.
} 
characterize Rio Grande do Sul's people. ${ }^{47}$ Nevertheless, the glorious legacy left by the Farrapos was significantly extended to those who had represented them in historical narratives. After Souza Docca's speech, Ramiz Galvão, as IHGB's official speaker, welcomed him in the usual manner and closed his greeting in the following manner:

With these words, anointed with love and full of enthusiasm, which brought the closure of your beautiful speech to be applauded by the Institute, with these same words I want to close this sincere greeting that I address to you in its name. You are a valuable brother of the Centaurs: you shall be, by our side, a valuable and great fighter for History's Truth and Justice. ${ }^{48}$

The heroes of the past relived in the historian of the present. The caudilhos were rehabilitated at the same time that Rio Grande do Sul's people entered their historiographical era. Thus, Souza Docca's mediation was legitimized by the concept of patriotism and the establishment of continuity between past and present.

\section{Revolution - Republican, federalist, patriotic, and Brazilian: the place and synthesis of heterogeneity in Farroupilha memory}

Between 1921 and 1932, the IHGB Review did not present new manifestations concerning Farroupilha memory. Nevertheless, there are some aspects to be analyzed in relation to the memory of Rio Grande do Sul's people in its entirety and to their main representative at the National Institute. In 1927, Souza Docca delivered a speech about the centenary of the combat of Santiago, part of the Cisplatine War. The voting and approval of a manifesto headed by some of IHGB's notable members, such as Afonso Celso and Max Fleiuss, and not signed by Souza Docca, preceded his speech. The fellow members of the IHGB agreed with the thesis that the combat of Ituzaingó (or of Passo do Rosário), led by Marquis de Barbacena during the Cisplatine War, had not been "derogatory to the nation". Fleiuss initiated the voting process by recalling and reaffirming previous works by members of the IHGB, among them influential figures such as Baron of Rio Branco and Count of Afonso Celso, who considered the controversial battle to be honorable to the Brazilian Arms. Therefore, it should be celebrated, albeit preserving the due respect towards the current continental scenario of peace among former adversaries. ${ }^{49}$ This fact is worthy of mention because, in 1923, Souza Docca had sided with Bento Manoel Ribeiro, a military man who acted in Ituizaingó and later was a leader in the War of Farrapos, in

\footnotetext{
${ }^{47}$ The epithet had already been in use by the members of the Literary Parthenon. Alexandre Lazzari, Entre a grande e a pequena pátria: literatos, identidade gaúcha e nacionalidade (1860-1910), Tese, Campinas, IFCHUnicamp, 2004. In the broader context of re-semantization of the gaucho people between 1889 and 1935, the rejection to caudilhismo as a characteristic of the political practices of Rio Grande do Sul was only another strategy among many associated with this process. Letícia Borges Nedel, “Caudilhismo, não! O papel da história linear na composição mítica do gaúcho: 1880-1935”, Em tempo de histórias, n. 5, ano 5, Brasília, 2001, p. 79-105. ${ }^{48}$ RIHGB, t. 90, vol. 144, 1921, p. 838.

49/dem, t. 101, vol. 155, 1927, p. 140-141.
} 
an issue of the IHGRS Review. In the publication, Souza Docca blamed Marquis of Barbacena for a supposed failure in this battle. ${ }^{50}$

What matters here is not so much the versions provided about that battle, which preceded the Farroupilha movement, but the existence of divergences among the contestant memories. ${ }^{51}$ The re-reading of Rio Grande do Sul's position in the calendar of celebrations and in the national Pantheon demanded a framing of the memory: in a speech delivered in 1927, Souza Docca silenced any reference to Bento Manoel, whom he had ardently defended from attacks that supposedly came from Barbacena's son in 1923. On the symbolic plane, the IHGB made concessions to the versions that dignified the Farroupilha leaders; however, the re-readings of the national memory were not allowed to contradict certain essential elements of the symbolic patrimony and the historiographical authority enshrined in the institution up to that moment. Here too, although in a different manner, the framing of memory was associated with the construction of intellectual legitimacies: Souza Docca, a novice historian, had no legitimacy to contradict the entire historiographical tradition defended by his predecessors.

As the centenary of the Farroupilha Revolution approached, topics related to its memory were increasingly more present in the IHGB's sessions. The icy crust and the reserved aura with which the subject was addressed were gradually broken..$^{2}$ The controversies and the divergences regarding the character of the Farrapos heroes were addressed beyond the regional historiographical and political debate, thus marking its presence at the IHGB. In any case, the process of rehabilitation of individual figures, and not of the character of the movement, continued in the same way it had started in 1921.

The fact that the Farroupilha centenary was celebrated at the IHGB was not new, since, as mentioned earlier, the Institute's celebratory sessions that occurred during the early years of the $20^{\text {th }}$ century had re-introduced the War of Farrapos in the sphere of national days which were regularly celebrated, just as it had occurred with the Revolution of Pernambuco in 1917, for instance. ${ }^{53}$ It was on this occasion that Homero Baptista delivered his

\footnotetext{
50RIHGRS, n. 3/4, 1923, p. 557-579, especially p. 561-563.

${ }^{51}$ The loss of the Cisplatine province affected the economic interests of those who would become Farrapos leaders years later, and it was pointed out as one of the tensions that built up between the latter and the political and military representatives assigned by the central government. See, for instance, Cesar Augusto Barcellos Guazzelli, "O Rio Grande de São Pedro na primeira metade do século XIX: Estados-nações e regiões províncias no rio da Prata", In: Luiz Alberto Grijó et al., Capítulos de história do Rio Grande do Sul, Porto Alegre, Ed. UFRGS, 2004, p. 91-120. In addition to Bento Manoel, other leaders such as David Canabarro and Bento Gonçalves also fought in the Cisplatine.

${ }^{52}$ Still in 1927, Eugênio Vilhena de Moraes chose "The surprise in Porongos" as the topic of his speech. This was a polemic episode that occurred at the end of the War of Farrapos in which many black combatants that were part of the Farroupilha forces were killed. The suspicion of an agreement between the adversaries, in this case Caxias and Canabarro, to facilitate and accelerate the peace process weighed heavily on this event. Vilhena de Moraes' speech was not entirely transcribed onto the session minutes, but the secretary's report about its content is enough to verify the ongoing rehabilitation of Farrapos leaders. What occurred in Porongos was supposedly a surprise and not betrayal, which explained the large amount of men killed in combat and exempted Canabarro from the suspicion of betrayal. RIHGB, t. 101, vol. 155, 1927, p. 259.

${ }^{53}$ On the celebration of the centenary of the Revolution of 1817, see Lucia Maria Paschoal Guimarães, "Entre a monarquia e a república: a Revolução Pernambucana de 1817 e suas representações no Instituto Histórico e Geográfico Brasileiro", In: Mônica L. Lessa; Silvia C. P. de Brito Fonseca (orgs.), Entre a monarquia e a república: imprensa, pensamento político e historiografia (1822-1889), Rio de Janeiro, Ed. UERJ, 2008, p. 151-164.
} 
speech about Brazilian revolutions, including that of Farroupilha after he mentioned the Revolution of Pernambuco. However, what draws attention in the case of the Farroupilha centenary is that the celebration was initiated three years earlier, in 1932, an emblematic year for the symbolic disputes that surrounded Vargas' government. ${ }^{54}$ They took place on September $20^{\text {th }}$ of that year and the subsequent years, up to $1935 .{ }^{55}$ The first festive occasion was incumbent upon Souza Docca, who once more occupied the tribune to speak about the event that he regarded as the greatest in gaucho history. ${ }^{56}$ This time, equipped with other documents and interpretations, Souza Docca resumed his analysis of one of the most ambiguous topics of his 1921 address: the Republican character of the Farroupilha Revolution.

At this point, it is necessary to clarify the concept of framing, which might suggest the imposition of a certain tradition. In the case of the Republican character of the Farroupilha Revolution, the demands for re-semantization that emerged in the beginning of the $20^{\text {th }}$ century did not seek to substitute a Monarchic memory with a Republican one. Above all, these demands concerned the establishment of a new coherence between the historical national and regional memories that had been construed as being Republican since the end of the $19^{\text {th }}$ century. ${ }^{57}$

\section{The revolutionary character of the conflict was configured by collective adhesion to an ideal: the federative Republic}

Since that time, Republican and federalist struggles in Rio Grande do Sul were marked by an anti-Monarchic discourse, which at times used the unique geographical, economic, ideological, and cultural characteristics of the Southern province as an argument for demanding autonomy. According to Ângela Alonso, the case of the gaucho scientific federalists (gathered at the September Twentieth Club) and the scientific federalists in the State of São Paulo was set apart from

\footnotetext{
${ }^{54}$ In 1932, the Constitutionalist Revolution of São Paulo represented more than a military conflict with the federal government. Several justifications used by the defenders of "outubrismo" ("Octobrism") to legitimate Washington Luís' deposition in 1930 were contested. Marco Cabral dos Santos; André Mota, São Paulo 1932: memória, mito e identidade, São Paulo, Alameda, 2010.

${ }^{55}$ In the ordinary session of June O4, 1932, Pedro Calmon had already talked about Giuseppe and Anita Garibaldi during the festivities that paid tribute to them and that were spreading throughout America and Europe. The Institute was associated with these events. The Italian ambassador of Brazil was present on this festive occasion. Anita and Garibaldi were regarded from the same perspective that guided the rehabilitation of individual figures that did not, as of yet, encompass the character of the conflict. According to Afonso Celso, the union of Italians and Brazilians was especially venerated, already verified in the marriages of the royal family in the $19^{\text {th }}$ century. RIHGB, vol. 166, 1932, p. 644-669, especially 661 and 668.

${ }^{56}$ The speech was entitled "Federative ideology in the Farroupilha crusade", Idem, Ibidem, p. 703-732.

${ }^{57}$ Other provinces, such as Pernambuco, had initiated the process of integrating regional and national Republican memories earlier. Either because the centenaries of the 1817 and the 1824 revolutions of Pernambuco occurred chronologically earlier, or because the institutionalization of history writing was more effective in that State in comparison to Rio Grande do Sul (as in the case of São Paulo, Pernambuco had founded a Historical and Geographic Archeological Institute back in the $19^{\text {th }}$ century, and enjoyed a more effective exchange with the IHGB; it also had a significantly higher number of members at the national house).
} 
other groups of the 1870 generation, because the contestation of Monarchic power happened through a re-edification of regional "old democratic traditions", such as the Farroupilha Revolution: "New heroes and 'revolutions' were bestowed with works and events of atonement, in which the gaucho scientific federalists were particularly prodigal, erecting their own heroes, such as Bento Gonçalves" ${ }^{58}$

Thus, Souza Docca seems to have resumed this process initiated in the field of literature in the $19^{\text {th }}$ century with the Literary Parthenon. He used the political discourse of Republican militants that glorified Farroupilha leaders, carried forward by himself and members of the IHGRS in the 1920s, in the spheres of memory and historiography. However, in the beginning of the 1930s, this process of rehabilitation of Farroupilha memory faced the imperative of its articulation with national memory. The new position taken by Rio Grande do Sul in national politics in the 1910s demanded, more than in the context of the federalist vindications of the $19^{\text {th }}$ century, its inclusion in the national Republican tradition.

The Republican ideas present among the farrapos were attributed to external and ill-intentioned influences by Souza Docca in 1921. In the context of Rio Grande do Sul in the 1830s, it now appeared as a natural tendency, a genuine fruit of the earth. According to the author, Republicanism was not the ideology espoused by the main Farroupilha leaders, but it had been adopted by a large number of agitators whose performance was no longer regarded with the suspicion shown previously. In 1932, the historian from Rio Grande do Sul considered the Republican agitators of 1835 as truly selfless men acting for a cause that they knew how to defend and disseminate to the extent of obtaining the main leaders' and the people's support. Thus, the farrapo leaders were invoked as people who had understood the necessities of the province and the best solution to deal with the differences between the Empire's parts: a federative Republic. They were no longer heroes, but the nation's greatest men. ${ }^{59}$

Contrary to what Araripe and Assis Brasil proposed in 1880, the concept of a Republic, in the context of criticism to the liberalism of the 1920s, was not identified with democracy, because it did not emphasize popular input and participation. It was defined by Souza Docca as the freedom and autonomy enjoyed by provincial administrations in relation to the Empire. From this perspective, the farrapos people were indeed Republicans advocating in favor of the establishment of a federation along with other Brazilian provinces. Their return to the Empire's bosom at the end of the war did not mean that they had given up fighting for the Republic; instead, it represented the leaders' patriotic abnegation when faced with the external threat that the Argentinian dictator Rosas posed to the Brazilian nation at that moment.

\footnotetext{
58Ângela Alonso, Ideias em movimento: a geração 1870 na crise do Brasil-Império, São Paulo, Paz e Terra, 2002, p. 292.

${ }^{59}$ In their discussion about the transition from old to modern biographies, Hartog and Dosse highlight that, in the context of the ascension of national States, the ancient heroes, regarded as semi-gods, were replaced by great men whose actions were connected to the promotion of collectivity. François Hartog, "Plutarque entre les Anciens et les Modernes". In: Plutarque, Vies parellèles, Paris, Gallimard, 2001, p. 9-49. François Dosse, 0 desafio biográfico: escrever uma vida, São Paulo, Edusp, 2009.
} 
Thus, Souza Docca presented new elements in the process of framing and rehabilitating Farroupilha memory. All at once, the movement that maintained a war against the Empire for ten years became not only dignified and glorious, but also patriotic and indispensable to the nation's integrity! After a true process of glorification that unfolded in the previous years concerning Farroupilha individuals who were now regarded as great heroes, selfless and courageous, untouched by the ideological controversies of the conflict - the very character of the event underwent a process of re-reading. The continuity between the Republican ideals of 1835 and 1889, and the Brazilian character of the movement was explicitly established..$^{60}$

Another problem present in Souza Docca's speech refers to the concept of revolution. At that moment, when Vargas' government had been threatened and won the constitutionalist "revolution", there was a dispute around the meaning of this concept, and Docca's text does not pull away from it. ${ }^{61}$ He argued that, if the leaders' goal had been solely the governor's deposition, as he had emphasized in 1921, the movement should be qualified as a revolt and not as a true revolution. ${ }^{62}$ By highlighting the Republican character that the conflict took at the end, Docca once again associated the concept of revolution with that of Republic, but this time emphasizing popular adhesion, now seen in a positive light, contrary to the way he had qualified it as the people's natural propensity to violence and disorder in 1921.

In summary, the revolutionary character of the conflict was configured by collective adhesion to an ideal: the federative Republic, which, in addition to functioning as an argument against the accusation of caudilhismo, mitigated separatism as a cause embraced by part of the movement. This is the explicit contraposition Souza Docca draws when initiating the "Federation" portion of his address. For him, only the "separatists" could deny the existence of a federative ideology among the farrapos. In his 1932 speech, a "separatist" was, above all, a person who equivocally interpreted the lofty federalist ideals that could be superseded only by patriotism as a moral trademark of the movement. This patriotism supposedly imposed the option of peace with the Imperials in favor of defending their homeland, threatened by Rosas. The nobility of this gesture was placed under suspicion by the historiographical thesis of separatism, which acquired the status of historical subject in the 1930s:

The verdigris of separatism tried to stain this gesture of purified gaucho civility by labeling it a trick, but it was unsuccessful, because the sentiment of Brazility of Rio Grande do Sul's people floats through our homeland's political constellation as that chant sung by Guerra Junqueiro's inspired muse: "So limpid, so high, that it even seems like a star in the sky is singing it".63

60RIHGB, vol. 166, 1932, p. 726.

${ }^{6}$ Vavy P. Borges, Tenentismo e revolução brasileira, São Paulo, Brasiliense, 1992, p. 13-18. According to the author, the designation "Revolution of 1930" given to the coup that deposed president Washington Luís was strengthened after the 1932 victory over the self-proclaimed "Constitutionalist Revolution", considered by the winners as a counterrevolution.

${ }^{62}$ RIHGB, op cit. p. 704.

63/dem, Ibidem, p. 731-732. 
Between the speeches of 1921 and 1932, which opened the long celebration of the farroupilha centenary at the IHGB, Souza Docca performed a veritable synthesis of the heterogeneous, not only obeying the imperatives of framing regional memory within the scope of national historical memory. Above all, he bestowed upon this representation the narrative coherence necessary to the persuasive dimension he wished to achieve. ${ }^{64}$ The author himself demonstrated that he was occupied with the contradictions and inconsistencies that the actions of the Farroupilha leaders brought to the representation he elaborated, referring to them as: "the mutations, zigzags, dubieties, certain acts that seem weird, contradictory, and at times even criminal and unworthy of certain individuals". ${ }^{65}$ The result was the convergence of the War of Farrapos with national historical memory as a revolutionary, Republican, federalist, Brazilian, and patriotic movement.

\section{Final considerations: the centenary, and the Farroupilha Revolution as a historiographical problem of national history}

It is important to highlight that the process of saving and glorifying Farroupilha past was preceded and followed by other initiatives that went beyond the IHGB's environment. In Rio Grande do Sul, the memory of the movement was disputed in several versions, not only in the State historical institute but also on the pages of periodicals and in official committees formed for the centenary celebration. The thesis of abrasileiramento ("Brazilianizing") of the Farroupilha Revolution is worthy of mention. ${ }^{66}$ The State government, the city halls, and the IHGRS gathered in committees that had the purpose of preparing for the big year of 1935. In addition to the exposure projected throughout the State by the festivities committee and the history congress that was prepared by the Institute, the government authorized the publication of a prominent historiographical work in 1933. The six volumes of $A$ história da Grande Revolução (History of the Great Revolution), by Alfredo Varela, came to light because of the relations between the government and the history institution. It registered on the cover page: "centenary commemorative edition, printed under the auspices of the Historical and Geographic Institute of Rio Grande do Sul and at the expense of the State government".

\footnotetext{
${ }^{64}$ Michel de Certeau, A escrita da história, Tradução de Maria de Lourdes Menezes, 2. ed., Rio de Janeiro, Forense Universitária, 2002, p. 96 e Paul Ricoeur, A memória, a história, o esquecimento, Campinas, Ed. Unicamp, 2007, p. 254. ${ }^{65}$ RIHGB, t. 166, 1932, p. 705.

${ }^{66}$ There is an extensive bibliography about the abrasileiramento of the Farroupilha Revolution - a 1930s intellectual enterprise that had the IHGRS as the central reference, and that endeavored to bring the origins, main motivations, and characteristics of the conflict closer to other Brazilian revolutions and problems, denying the rioplatense influences it might have suffered. Among the most important works are leda Gutfreind's A historiografia rio-grandense, 2. ed., Porto Alegre, UFRGS, 1998, and Marlene M. de Almeida's Introdução ao Estudo da Historiografia Sul-rio-grandense: inovações e recorrências do discurso oficial (19201935), Dissertação, Porto Alegre, IFCH-UFRGS, 1983. Another important work, by anthropologist Ruben Oliven, also approaches the topic by focusing on the tense construction of Rio Grande do Sul's regional identity, which oscillates between integration and isolation. According to Oliven, in Rio Grande do Sul, the emphasis on the uniqueness of its culture and the promotion of separatist ideas has been largely used to reinforce the arguments of its representatives in political negotiations with the Brazilian federations in times of economic crisis. Ruben George Oliven, A Parte e o Todo: a diversidade cultural no Brasil-Nação, Petrópolis, Vozes, 1992.
} 
Souza Docca, then, positioned himself against Alfredo Varela's work on the pages of Jornal do Comércio, circulated in Rio de Janeiro, where both lived at that time, employing all his effort to refute the latter's thesis that the farrapos had been adepts of separatism by virtue of their precarious feeling of "Brazilianity". Thus, the scenario of symbolic dispute around farroupilha memory once more extrapolated regional boundaries, and the debate took on the guise of what is commonly qualified as a "dialogue of deaf", as Varela dedicated himself to addressing mainly the objections about his work's style, while Docca was mostly concerned with the issue of separatism and the revolution's "Brazilianity".67

At the IHGRS, a letter from a gaucho intellectual who had been following the controversy between the historians demanded the Institution to position itself more clearly by refuting Varela's separatist thesis about the farrapos ${ }^{68}$ After long years of being used in political discourses and decanted in regionalist literature, the rehabilitation of farroupilha memory in strict connection to the institutionalized writing of regional and national history demanded its dues.

Close to its centenary, the process of converting the Farroupilha Revolution simultaneously into an object of national civic worship and a historiographical object oscillated between the demands of memory and history. This scenario provoked passionate reactions from the intellectuals from whom pronouncements full of erudite references mixed with national historiographical tradition were allegedly and increasingly expected, in lieu of inflamed political speeches. However, once the "scientific" procedures legitimated by the institutions were respected, the historians' texts were rendered to political use at once, as it is possible to be verified in the stream of celebratory speeches delivered at the farroupilha centenary. ${ }^{69}$

Designated as the person responsible for the celebratory speech of 1934, Basílio Magalhães did not entirely agree with the patriotic version of the ten years of the revolution as glorious, and he based his address on Souza Docca's opponent. ${ }^{70}$ The reasons for this disagreement related more to problems of the present than those of the past. Magalhães mentioned an episode

\footnotetext{
${ }^{67}$ On the style and the concept of history in Varela, see Jaisson Oliveira da Silva, A epopeia dos titãs do Pampa: historiografia e narrativa épica naHistória da Grande Revolução, de Alfredo Varella, Dissertação, Porto Alegre, PPGH - UFRGS, 2010. His intention of writing a grand epic can be compared to what had been done in São Paulo in relation to the bandeirantes since the end of the $19^{\text {th }}$ century. Antônio Celso Ferreira, $A$ epopeia bandeirante: letrados, instituições, invenção histórica (1870-1940), São Paulo, Ed. UNESP, 2002.

${ }^{68}$ The letter that Castilhos Goycochea wrote to the IHGRS' secretary prompted the formation of a committee charged with producing a verdict about Varela's work. Even though it was composed of adversaries who strongly opposed Varela's separatist version, the committee had to be mild in its conclusions, since the issue referred to one of the IHGRS' members, who was also friends with the mediator. In the end, the committee merely stated that the IHGRS did not endorse all the theses circulated in its premises. RIHGRS, 40 trim., 1934, p. 268.

${ }^{69}$ According to Grijó in "Entre a barbárie e a civilização: os conflitos armados no período republicano", In: Eduardo Santos Neumann; Luiz Alberto Grijó (orgs.), O continente em armas: uma história da guerra no sul do Brasil. Rio de Janeiro, Apicuri, 2010, p. 182-183, a veritable civilizing process unfolded in the southern state at this time. Men were leaving their swords for the quill. The IHGB and the IHGRS had an important role in this process. RIHGRS, 40 trim., 1934, p. 268.

${ }^{70}$ Already in his 1932 speech, Docca referred to the equivocal interpretations about the Italians' role (Zambeccari and Garibaldi) in the propagation of Republican ideas circulated by Basílio de Magalhães, and based on Assis Brasil and Alfredo Varela, during the farroupilha period. RIHGB, vol. 166, 1932, p. 716-717.
} 
that preceded the Revolution of 1930 in which, while occupying a representative's position, he vigorously opposed the political use that one of his contenders made of the farroupilha past. ${ }^{71}$ Then, he argued that separatism was not necessarily bad, and that it had been present in Brazil since the $17^{\text {th }}$ century. Considering that he was born in Minas Gerais, opposed the Revolution of 1930, and wrote books about bandeirismo, he seemed to be referring to the recent context of the conflict with Vargas' government in the State of São Paulo, given that separatist manifestations had also taken place there with the purpose of mobilizing the population to side with São Paulo. ${ }^{72}$ After that, he affirmed the existence of separatism among the farrapos, also relying on another historian from Rio Grande do Sul, Aurelio Porto, Souza Docca's fellowman at the IHGRS, who also researched the "O Processo dos Farrapos" ("The Process of the Farrapos") in the federal capital. ${ }^{73}$

However, the dispute between the memories extrapolated the issue of separatism, and Magalhães sought to weaken Souza Docca's intellectual authority by not referring to his 1932 speech even once, contrary to those that had been occupying the IHGB's tribune to speak about the subject since then. Putting himself in the place of a historian in the present, Magalhães belittled the Colonel-Lieutenant's historiographical patent, ironizing his authority before renowned historians, such as Alfredo Varela, Assis Brasil, and Aurelio Porto: "Addressing such a relevant question, which demands thorough examination and profound meditation, how could I, a simple and inexperienced soldier, dare to diverge from these Marshals of our letters, some fortunately still alive, and others already beyond this world?"74 Nevertheless, despite his hostility against Souza Docca, Magalhães, just like Varela, did not disagree with the necessity of rehabilitating the farrapos, especially the movement's leaders, in the national memory, thus ratifying patriotic intentions of peace between farrapos and the Imperials. ${ }^{75}$ Their opinions diverged in relation to the reasons but not the fairness of glorifying farroupilha leaders. They disagreed, in fact, in regard to the use of the past in the present.

Besides this testimony, the success of the attempts to re-read the farroupilha past and its integration into national memory can be measured by the declarations made by the IHGB's president in 1921 and 1932. In 1921, after Souza Docca's speech, Afonso Celso referred to the Farroupilha Revolution as a set of "serious events", whose "separatist attempt" should not be remembered as an

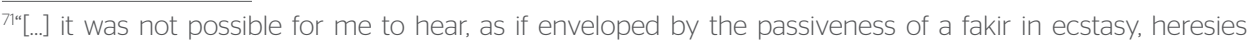
and mistakes concerning our nation's greatest episodes, explored with subversive purposes. I protested, I corrected, I elucidated, and I did so when the tribune of that federal assembly was already closing its doors for me definitively, and when, after the victory of the Revolution of 1930, I no longer disposed of press columns to keep myself within public debates". RIHGB, vol. 169, 1934, p. 381.

${ }^{72}$ If, in Rio Grande do Sul, any type of political mobilization involved calling upon farroupilha legacies, São Paulo had its own bandeirante epic, which, in the context of the constitutionalist revolution, provided elements for a discourse that bordered on separatism. Marco Cabral dos Santos; André Mota, São Paulo 1932: memória, mito e identidade, São Paulo, Alameda, 2010.

${ }^{73} \mathrm{O}$ Processo dos Farrapos (The Process of the Farrapos), stored in the National Archive, was copied and became Souza Docca's and Aurelio Porto's research project in the 1930s, especially prior to the farroupilha centenary.

${ }^{74}$ RIHGB, vol. 169, 1934, p. 385.

75/dem, Ibidem, p. 398.
} 
example to the nation. ${ }^{76}$ In 1932, before Souza Docca's speech, the president still referred to the conflict as a "painful episode of our history", but mentioned that "lasting impressions" resulted from studying it, such as the

heroism manifested by both parts, the greatness of some figures, such as Bento Gonçalves and de Caxias, the honorable conclusion of the struggle, and Rio Grande do Sul's complete reintegration into Brazil's political communion, in whose heart it has always been and will always be incorporated. ${ }^{77}$

Unintentionally, Afonso Celso revealed each element of the narrative coherence assembled by Souza Docca and a significant part of the IHGRS' members, concealing only Docca's efficient strategy of double institutional insertion that had a fundamental role in the dispute around farroupilha memory. The Brazilianity thesis was victorious at the heart of history's dwelling in Brazil. 